\title{
THE MEDICAL ACTIVITIES OF MID-NINETEENTH-CENTURY CHEMISTS AND DRUGGISTS, WITH SPECIAL REFERENCE TO WAKEFIELD AND HUDDERSFIELD
}

by

\author{
HILARY MARLAND*
}

During the eighteenth and nineteenth centuries, many facilities were created with the express aim of providing medical care and treatment. The foundation of large numbers of dispensaries and infirmaries, the establishment of a formal channel of medical relief through the agency of the New Poor Law, and the setting up of a network of friendly societies, with facilities for the pecuniary and medical relief of their sick members, gave the poor and labouring classes of this period more access to medical treatment than they had ever had before. Meanwhile, those wealthy enough to pay for private medical care could utilize the services of a growing number of qualified medical practitioners. Yet rich and poor alike continued to resort to a variety of "unqualified" or "fringe" sources of medical aid. For some, such forms of medical treatment supplemented treatment by a "regular" practitioner; for others, with limited access or money, or with a preference for fringe methods, these were the sole means of medical relief.

A wide variety of labels has been thrown up to describe the unqualified, influenced by a practical need to distinguish this group from the protessionals and by sociological terminology, the fringe, periphery, alternative or unorthodox practitioners, paramedics, quacks, and so on. The labels refer to a heterogeneous collection of individuals and groups, using varying methods of diagnosis and treatment, drawing on folk traditions, ancient remedies or the "new sciences" of, for instance, hydropathy, homeopathy, mesmerism or medical botany, or, in some cases, on showmanship, trickery or commercial enterprise. Until at least the mid-nineteenth century, we are not really in position to distinguish between professional practitioners and the fringe in terms of the quality of treatment given, its scientific standing or success rate. In such circumstances, it is perhaps most useful to distinguish between fringe and orthodox medicine on the grounds of legal and professional inclusion and exclusion. ${ }^{1}$ The nineteenth century saw not only the survival of traditional fringe practitioners-folk

*Hilary Marland, PhD, Medisch Encyclopedisch Instituut, Vrije Universiteit, van der Boechorststraat 7, 1081 BT Amsterdam, The Netherlands.

The author gratefully acknowledges the assistance of her former colleagues at the Wellcome Unit, Oxford, where she was a Research Fellow when this paper was written; also the support of the ESRC, who funded the Fellowship (ref. A23320031): and John Pickstone for his valuable comments.

${ }^{1}$ Roy Porter, 'Quacks: an unconscionable time dying' unpublished paper, Wellcome Institute for the History of Medicine, London, 1983, p. 1. For the nature of the fringe, see W. F. Bynum and Roy Porter (editors), Medical fringe and medical orthodoxy, 1750-1850, London, Croom Helm, 1986; and Roger Cooter, 'Interpreting the Fringe', Bull. Soc. soc. Hist. Med., 1981, 29: 33-36. 


\section{Hilary Marland}

healers, wise-women, midwives, bone-setters, and itinerant quacks-but also the flourishing of new unorthodox and para-medical groups, including homeopathists, hydropathic practitioners, medical botanists, and chemists and druggists. If we wish to take into account all individuals and facilities involved in the dispensing of medical care, and to build up a picture of the total amount and nature of medical treatment available, then we cannot leave the unqualified or fringe practitioner out of our analysis. This paper will examine the activities, most specifically the medical activities, of one of the new groups of medical personnel to emerge during the nineteenth century, the chemists and druggists, and attempt to assess their role in the provision of medical advice and treatment.

By the mid-nineteenth century, chemists and druggists made up the most numerous group of para-medical personnel. For this reason alone, a study of this group and their functions would seem to be useful in making any assessment of the range and form of medical assistance available during the nineteenth century. In addition to being numerous, however, chemists and druggists were also versatile, offering a very wide range of medical services. While the most clearly-defined function of the nineteenthcentury chemist and druggist was to make up the prescriptions of qualified medical men, this was not normally their most important function, and they also engaged themselves in a number of what can be described as medical or even fringe activities. These activities, which included "over-the-counter-prescribing", the making up of family recipes, and the sale of a wide range of drugs and patent remedies, accounted for the largest proportion of the chemist and druggist's trade.

Moreover, in professional and social terms, chemists and druggists constituted an ambiguous group. While involved in activities which aligned them with the rest of the fringe, the middle-class status of many chemists and druggists, their growing professionalism, frequent expertise, close working relationship with the medical profession, and, in many cases, wealth and high social standing in the communities in which they worked, made them distinct from other fringe groups. The chemists and druggist were one of the few fringe or para-medical groups to emerge during this period who could lay claim to some form of professional standing. By the mid-nineteenth century, they were slowly organizing and taking on some features of a professional group. The formation of the Pharmaceutical Society in 1841, the establishment of the Pharmaceutical Journal, the setting up of schools and courses specializing in the education of pharmacists, and the development of uniform standards of training and examination, which became compulsory under the 1868 Pharmacy Act, were important aspects of this process. Already, by 1842 , the Pharmaceutical Society had 2,000 members. ${ }^{2}$ Yet these developments did not lead to a narrowing down of the functions of the chemists and druggists to the compounding and dispensing of prescriptions; nor did they inhibit their fringe activities.

This paper will be limited in both geographical scope and time. Many of the data have been taken from a survey of the West Riding, with special reference to Wakefield and Huddersfield, although an effort has been made to place developments in these

\footnotetext{
${ }^{2}$ For more on these developments, see G. E. Trease, Pharmacy in history, London, Baillière, Tindall \& Cox, 1964; F. N. L. Poynter (editor), The evolution of pharmacy in Britain, London, Pitman Medical Publishing, 1975.
} 
two communities into a national perspective. ${ }^{3}$ Wakefield, primarily a market and service centre, experienced only a steady rate of industrial growth during the nineteenth century. Huddersfield was, on the other hand, a rapidly expanding textile community, an exemplary nineteenth-century industrial town. However, both experienced urban development and population growth during the early and mid-nineteenth century-Wakefield in a rather less dramatic form-and the rise in the number of chemists and druggists appears to have been closely tied to this urbanization process. In addition, the paper will cover only the middle decades of the nineteenth century, using the Apothecaries' Act of 1815 and the 1868 Pharmacy Act as rough boundaries. During the early- and mid-nineteenth century, there was a remarkable increase in the numbers involved in pharmacy. This was an era of special significance for the chemists and druggists, not only because of their remarkable growth in numbers, but also because it saw their independence of the apothecaries, the clause tc control chemists and druggists being dropped from the Apothecaries' Act, and, at the end of this era, the campaign for, and the passing of, the Pharmacy Act had important implications for the professionalization and self-identity of the chemist.

Overall, chemists and druggists have received scant attention by medical historians. Those studies that have been undertaken have tended to concentrate on the growing professionalism of this group during the nineteenth century, ${ }^{4}$ and on the competition between chemists and druggists and general practitioners for dispensing work. However, it is not issues relating to the professionalization of this group that will concern us here. Nor will this paper give much coverage to the training of chemists and druggists during the nineteenth century, or to their economic status and standing in the local community. While it is generally accepted that chemists and druggists involved themselves in less orthodox activities, and that over-the-counter-prescribing and the sale of drugs directly to the public were vital components of their businesses, these functions have not been fully described and analysed. This paper will look in some detail at the medical activities of the chemist and druggist, most specifically at those which took him beyond his role as a medicine supplier, and which could be seen as placing him in the context of medical practice.

Data on chemists and druggists, as compared with information on other sections of the medical fringe during the nineteenth century, are widely available. In contrast with other fringe elements, chemists and druggists were easily identifiable, in most cases having a fixed location, their shops. For the Wakefield and Huddersfield survey, the starting-points for a collection of numerical data were the census returns and trade directories. While figures taken from these sources tend on the whole to understate the size of the medical fringe, the data on chemists and druggists appear to be more complete and reliable (especially if the two sources of data are used in conjunction with

\footnotetext{
${ }^{3}$ This paper forms a supplement to a wider survey of medical practice and medical provisions in Wakefield and Huddersfield during the nineteenth century. See Hilary Marland, Medicine and society in Wakefield and Huddersfield 1780-1870, Cambridge University Press, 1987.

${ }^{4}$ For example, J. K. Crellin, 'The growth of professionalism in nineteenth-century British pharmacy', Med. Hist., 1967, 11: 215-227 and 'Leicester and 19th century provincial pharmacy', Pharm. J., 1965, 195: 417-420; L. G. Matthews, History of pharmacy in Britain, Edinburgh, E. \& S. Livingstone, 1962. For a new interpretation of events leading up to and the reasoning behind the formation of the Pharmaceutical Society, see S. W. F. Holloway, 'The orthodox fringe: the origins of the Pharmaceutical Society of Great Britain', in Bynum and Porter (editors), op. cit., note 1 above, pp. 129-157.
} 


\section{Hilary Marland}

each other). Trade directories listed the number of chemists' shops and individual chemists in the year of publication, and indicated the location of the shops and, where applicable, separate residences. The census returns gave further details of the residences as well as information on household size and structure, and the employment of apprentices, assistants, and servants. The numerical data were supplemented by other sources, the most useful and prolific of which were local newspapers. Advertisements placed by chemists and druggists in the local press gave valuable information on their retail functions: the range of services which they offered, the products they sold, and, perhaps most significantly, groups to whom they directed their sales promotions. Parliamentary reports and medical journals, meanwhile, constituted valuable, albeit frequently biased, sources of information, their main concern being with the dangers of unqualified advising and prescribing, and the competition of chemists and druggists to qualified medical men. The studies of social geographers and economic historians, especially into the history of retailing, were found to be valuable supplements to the literature of medical historians on the activities of the chemists and druggists. ${ }^{5}$

From the seventeenth century onwards, the traditional pharmaceutical practitioners, the apothecaries, had been extending their role as dispensers of drugs, and turning to general medical practice. This transformation was accompanied during the late-eighteenth and nineteenth centuries by pressure from the chemists and druggists, who challenged and undercut the apothecaries' dispensing trade. ${ }^{6}$ As Irvine Loudon has suggested, by the turn of the nineteenth century, the ability of the apothecaries and surgeon-apothecaries to make a substantial living from the practice of pharmacy had been greatly diminished, as the number of dispensing chemists and druggists increased. The chemists and druggists dealt directly with the public, undercutting the counter-trade of the apothecaries, and usurping their traditional role by dispensing for physicians. It was not unknown even for physicians to utilize the chemist's shop to give free medical advice and to prescribe, the profits from the sale of medicines being divided between the chemist and physician, effectively cutting out the apothecary. ${ }^{7}$ The apothecaries' transition to medical practice was speeded up by the passing of the Apothecaries' Act in $1815 .^{8}$ By early in the nineteenth century the title "apothecary" had all but disappeared from town directories, as this group was absorbed into the category of "surgeon".

\footnotetext{
${ }^{5}$ See, for example, D. Alexander, Retailing in England during the industrial revolution, London, Athlone Press, 1970; James H. Johnson and Colin C. Pooley (editors), The structure of nineteenth century cities, London, Croom Helm, 1982, part 3; Michael J. Winstanley, The shopkeeper's world 1830-1914, Manchester University Press, 1983. For the background to the evolution of Boots, see Stanley Chapman, Jesse Boot of Boots the Chemists. A study in business history, London, Hodder \& Stoughton, 1974.

6 Originally the "drugster" or "drugman" acted as the middleman in the passing of drugs between the importer and apothecary. During the seventeenth century, his functions were combined with those of the "chymist", a "dabbler in chemical medicines". By 1700, the terms were used interchangeably in London, and by 1750 , wholesale and retail druggists' shops had been established in the provinces. J. F. Kett, 'Provincial medical practice in England 1730-1815', J. Hist. Med., 1964, 19: 19-20.

${ }^{7}$ Irvine Loudon, 'A doctor's cash book: the economy of general practice in the 1830s', Med. Hist., 1983, 27: 265-266. See also, Irvine Loudon, 'The vile race of quacks with which this country is infested', in Bynum and Porter (editors), op. cit., note 1 above, pp. 106-128.
} 
Meanwhile, changes in terminology and practice were paralleled by a considerable growth in the number of chemists and druggists (as shown in Table I), in part stimulated by population growth, especially in urban areas. In 1780 , for example, there were just two chemists' shops in Huddersfield. By 1822, there were five, by 1837 nine, and by 1870 nineteen. During the 1790 s, Wakefield was also served by two chemists. By 1822, there were six chemists' shops, and between 1822 and 1870, the number of them more than trebled to nineteen. ${ }^{9}$ Many other communities, particularly those undergoing rapid urbanization, saw similar increases in the number of chemists' shops during the late-eighteenth, and, more particularly, the early-nineteenth centuries. In Sheffield, for example, the first druggist's business was recorded in 1750. According to Austen's sources, by 1774 there were three chemists and druggists

\section{TABLE I. THE RATIO OF CHEMISTS AND DRUGGISTS TO QUALIFIED MEDICAL PRACTITIONERS, 1790-1870†}

$\begin{array}{ccccccc}\text { Year } & \begin{array}{c}\text { Chemists and Druggists } \\ \text { (shops)* }\end{array} & \begin{array}{r}\text { Qualified Medical Practitioners } \\ \text { (physicians)* }\end{array} & \begin{array}{c}\text { Ratio of Chemists and Druggists to } \\ \text { Qualified Medical Practitioners } \\ \text { Wakefield }\end{array} \\ \text { Huddersfield } \\ 1790 & 2(2) & 2(2) & 9(3) & 4(0) & 1: 4.5 & 1: 2 \\ 1822 & 6(6) & 5(5) & 18(6) & 13(3) & 1: 3 & 1: 2.6 \\ 1828 & 10(9) & 6(5) & 20(6) & 14(3) & 1: 2 & 1: 2.3 \\ 1837 & 13(12) & 9(9) & 19(4) & 17(3) & 1: 1.5 & 1: 1.9 \\ 1847 & 20(19) & 14(14) & 25(6) & 21(3) & 1: 1.3 & 1: 1.5 \\ 1853 & 19(17) & 16(15) & 26(7) & 22(5) & 1: 1.4 & 1: 1.4 \\ 1861 & 19(18) & 18(17) & 22(4) & 23(4) & 1: 1.2 & 1: 1.3 \\ 1866 & 19(18) & 22(20) & 19(5) & 21(3) & 1: 1 & 1: 0.95 \\ 1870 & 19(19) & 21(19) & 18(3) & 21(3) & 1: 0.95 & 1: 1\end{array}$

t A note of caution should be added here. There may be minor inaccuracies in the tables (and in figures given in the text), a result of omissions and discrepancies in trade directory listings, particularly for the earlier years.

*The number of chemists' shops and physicians are represented by the figures in brackets.

Sources: Universal British directory, op. cit., note 9 above; E. Baines, op. cit., note 9 above; W. Parson and W. White, West Riding Yorkshire directory, Leeds, 1828; W. White, 1837 directory, op. cit., note 9 above; W. White, Directory and topography of Leeds, Bradford, Halifax, Huddersfield, Wakefield, and the whole of the clothing districts of the West Riding of Yorkshire, Sheffield, 1847; W. White, Directory and gazetteer of Leeds, Bradford, Halifax, Huddersfield, Wakefield and the whole of the clothing districts of Yorkshire, 1853, reprinted Newton Abbot, David \& Charles, 1969; W. White, Directory and topography of the Borough of Leeds, Wakefield, Bradford Huddersfield, etc., Sheffield, 1861; W. White, Directory of Leeds, Bradford, Huddersfield, Halifax, Wakefield, Dewsbury, Sheffield, 1866; W. White, 1870 directory, op. cit., note 9 above.

\footnotetext{
${ }^{8}$ For more on these developments, see, for example, B. Hamilton, 'The medical professions in the eighteenth century', Econ. Hist. Rev., 1951, 2nd series, 4: 159-169; S. W. F. Holloway, 'The Apothecaries' Act, 1815: a reinterpretation', parts I and II, Med. Hist., 1966, 10: 107-129, 221-236; Trease, op. cit., note 2 above, pp. 169-174.

${ }^{9}$ T. Dyson, The history of Huddersfield and district from the earliest times down to 1932, Huddersfield, The Advertiser Press, 1932, p. 467; Universal British directory of trade and commerce (1790-98); E. Baines, History, directory and gazetteer of the County of York, vol. I, 1822, reprinted Wakefield, David \& Charles, 1969; W. White, History, gazetteer, and directory, of the West Riding of Yorkshire, vol. I, Sheffield, 1837; W. White, General and commercial directory of Leeds, Huddersfield, Wakefield, Dewsbury, Batley, Heckondwike, Holmfirth, Morley, Pudsey, and all the parishes and villages in and near those populous districts of the West Riding, ..... Sheffield, 1870.
} 


\section{Hilary Marland}

(including one female druggist), by 1797 ten, by 1817 seventeen, by 1838 thirty-eight, and by 1841 fifty-six. (By comparison, it has been estimated that there were a total of seven physicians, surgeons, and apothecaries practising in Sheffield in 1774; by 1841, the printed census returns give a figure of eighty-seven, including an unspecified number of medical students. ${ }^{10}$ ) Between 1825 and 1853 , the numbers of chemists and druggists in Nottingham more than doubled from twenty-two to forty-seven (while the number of qualified medical practitioners rose from thirty to forty) ${ }^{11}$ By 1851,114 individuals ( 105 businesses) were listed as chemists and druggists in the Bristol census enumerators' books, together with a similar number of qualified medical men. ${ }^{12}$

This increase in numbers, which was most significant in the first half of the nineteenth century, could perhaps have resulted from one of three developments, or from a combination of the three. The first possibility was that a growing number of medical practitioners abandoned their dispensing functions during this period, and turned over the making up of prescriptions to the chemists and druggists, which led to an increased volume of trade for this group. Secondly, the increase could be explained quite simply by the population growth of the two communities, which resulted in a larger market for the chemists and druggists' services. The third possibility is that the inhabitants of the two towns made growing use of the chemists' services, and thus facilitated a rise in their numbers.

Although there was an increase in the number of qualified medical men practising in Wakefield and Huddersfield during the nineteenth century, this increase did not keep pace with the growth in the number of chemists and druggists over the same period (see Table I). Between 1822 and 1853, the number of qualified medical men in Wakefield increased from eighteen to twenty-six $(44 \%)$. Over the same period, the number of chemists and druggists rose from six to nineteen $(217 \%)$. In Huddersfield, the number of qualified medical men increased at a faster rate during the same thirty-year period, but by no means kept up with the rise in the number of chemists and druggists in the town. In 1822, there were thirteen qualified medical men resident in Huddersfield. By 1853 , there were twenty-two (an increase of $69 \%$ ). The number of chemists and druggists, meanwhile, increased from five to sixteen $(220 \%)$, an almost identical rate of increase to that experienced in Wakefield. After $c$. 1853, the number of practising medical men in Wakefield began to fall off, from twenty-six in 1853 to eighteen in 1870 . Over the same period, the number of chemists and druggists remained steady, there being roughly nineteen in business in the town at any one time. In Huddersfield, there was also a small decline in the number of qualified medical practitioners between 1853 and 1870 , from twenty-two to twenty-one. In the same two decades, five more chemists and druggists established themselves in the town, giving a total in 1870 of twenty-one. ${ }^{13}$

10 J. Austen, Historical notes on old Sheffield druggists, Sheffield, J. W. Northend, 1961, pp. 10-12, 15, 26, 35, 47; Abstract of the answers and returns made pursuant to Acts $3 \& 4$ Vic. c. 99, and 4 Vic. c. 7, intitled respectively 'An Act for taking an account of the population of Great Britain', and 'An Act to amend the Acts of the last session for taking an account of the population'. Occupation abstract, part 1. Wallis's listing of eighteenth-century medics has counted at least four chemists and druggists and nine surgeons and apothecaries for the period around 1774. P. J. and R. V. Wallis, Eighteenth century medics (subscriptions, licenses, apprenticeships), Newcastle, Project for Historical Biobibliography, 1985.

${ }_{11}$ Trease, op. cit., note 2 above, p. 182.

12 P. S. Brown, 'The providers of medical treatment in mid-nineteenth-century Bristol', Med. Hist., 1980, 24: 297-314.

${ }^{13}$ Sources as for Table I. 
These figures can be expressed in a more meaningful way by demonstrating the relationship between qualified medical men and chemists and druggists in terms of ratios (see the last two columns of Table I). A nationwide survey, using information extracted from the 1841 census returns, concluded that there was one chemist and druggist in Great Britain to every two medical practitioners. ${ }^{14}$ By the 1850 s and ' 60 s, the proportion of chemists and druggists appears to have been even higher. In 1822, there was one chemist and druggist to every three medical practitioners in both Wakefield and Huddersfield. By 1866, the ratios were one to one (see Table I). The printed census returns indicate that by the mid-nineteenth century, some counties, particularly the more urbanized ones, recorded higher numbers of chemists and druggists than qualified medical practitioners. In the West Riding, for instance, 754 physicians and surgeons and 1,039 chemists and druggists were listed in the 1851 census returns; in Lancashire, there were 1,171 medical practitioners compared with 1,794 chemists and druggists in 1851; in the smaller and more rural county of Lincolnshire the figures were 304 and 424 respectively. ${ }^{15}$

\section{II}

The faster growth in the number of chemists and druggists as compared with medical practitioners was perhaps partly offset by an increasing tendency on the part of medical men to turn over the function of dispensing to the druggist. Until the mid-nineteenth century it was common practice for individuals to combine the activities of a surgeon-apothecary and druggist, or even a physician and druggist. During the first decades of the nineteenth century, for example, M. Barber of Wakefield, "Surgeon, etc.", offered his services "IN EVERY DEPARTMENT OF HIS PROFESSION" and also ran a chemist's shop, his late father's, in the town centre, where he dispensed his own prescriptions and those of other medical men. In 1823, Dr Bell (formerly of Bath and Hull) "... entered to the Premises occupied by Messrs Mitchell and Birkett, surgeon-apothecaries and druggists, ..." and "respectfully solicited" the continued patronage of the inhabitants of Wakefield and its vicinity. ${ }^{16}$ During the first half of the nineteenth century, many medical men continued to refer to themselves in advertisements as "surgeons and apothecaries", indicating the duality of their functions. Indeed, it is often difficult to determine whether individuals were medical practitioners who engaged in pharmaceutical activities, or druggists who engaged in medical practice.

Pharmacy did not pass entirely out of the hands of the medical profession. As Loudon has demonstrated, the suggestion that general practitioners should abandon pharmacy and sever their traditional links with the functions of the apothecaries was not widely implemented during the first half of the nineteenth century, and for many general practitioners the dispensing of medicines continued to provide their main

\footnotetext{
14 'Unqualified medical practitioners', Med. Times Gaz., 1853, 2: 143.

15 Figures cited from Philip Swan's forthcoming thesis, 'The development of the medical and auxiliary professions in the West Riding during the nineteenth century', (Humberside College of Higher Education), which examines the relationship, numerical and otherwise, between qualified medical practitioners and chemists and druggists, using data extracted from the 1851 and 1871 West Riding census enumerators' books, and 1841 to 1881 printed census returns for England.

${ }^{16}$ Wakefield Star, 5 January 1810; Wakefield and Halifax Journal, 27 June 1823.
} 


\section{Hilary Marland}

source of income. ${ }^{17}$ Individuals such as William Rowlandson of Wakefield, "Surgeon, Chemist, etc., etc.", who, in 1842, announced in the Wakefield Journal that ". . . he has opened an Establishment for the Dispensing of Medicine, where he intends carrying on the Business of Chemist and Druggist, in all its branches", ${ }^{18}$ were probably not untypical. Rowlandson later abandoned the pharmaceutical side of his enterprises, or at least gave up his open shop, to concentrate on surgery and midwifery. At the end of the nineteenth century, there were still large numbers of "dispensing doctors", and many panel doctors kept their dispensaries going until after World War II and the establishment of the National Health Service. But around the mid-nineteenth century, it appears that many regular practitioners abandoned their open shops and ceased to advertise their pharmaceutical services. The abandonment of these activities coincided closely with the passing of the 1858 Medical Act, and efforts to tighten up the professional structure, to create a code of ethics, and to improve the status of the medical practitioner. It seems likely that some doctors, particularly the more status-conscious ones, did allow the chemist to take over the business of dispensing prescriptions during the mid- to late-nineteenth century, therefore facilitating an expansion in the chemist's trade.

However, it is inconceivable, especially when we remember that in communities such as Wakefield and Huddersfield there was one chemist to every medical practitioner by the $1860 \mathrm{~s}$, that the chemist could have survived solely on an income from this source. Of course, no chemist attempted to do this, and it seems likely that some undertook virtually no prescribing work whatsoever. Bell and Redwood even suggested that during this period most chemists and druggists "rarely saw a physician's prescription and therefore had little occasion for a knowledge of dispensing". ${ }^{19}$ (Indeed, it appears that most chemists and druggists felt that the educational standards of the Pharmaceutical Society were too high and largely irrelevant to their functions.) During the 1830s and '40s (when in theory there was considerably less competition for dispensing work between chemists themselves), a good-class family business in Highgate, London, in addition to dispensing, prescribed and sold drugs to their customers, and retailed a wide range of non-pharmaceutical goods, domestic recipes, and veterinary preparations. Even a large business concern like this, which made up the prescriptions of a number of eminent London doctors, including four Presidents of the Royal College of Surgeons, was making up only an average of 350 prescriptions per annum. ${ }^{20}$

\section{III}

One can conclude that trade with the general public was of greater importance than dealings with the medical profession for most nineteenth-century druggists. Many combined the manufacture, wholesale and retail of pharmaceutical preparations, and were involved in non-pharmaceutical activities. The sale of drugs without prescription,

${ }^{17}$ Loudon, 'A doctor's cash book', op. cit., note 7 above, p. 267.

18 Wakefield Journal, 6 October 1842.

$19 \mathrm{~J}$. Bell and T. Redwood, Historical sketch of the progress of pharmacy in Great Britain, London, Pharmaceutical Society of Great Britain, 1880, p. 163.

${ }^{20}$ A. E. Bailey, 'Early nineteenth century pharmacy', Pharm. J., 1960, 185: 208-212. 


\section{The medical activities of mid-nineteenth-century chemists and druggists}

the ingredients of remedies, patent preparations, family medicine chests, and the chemists' own special cure-alls were staple parts of the chemists and druggists' trade during the nineteenth century. Most offered advice in addition to medicines. All dealt directly with the public in a similar way to chemists today, but their range of activities, medical and otherwise, was far broader, and the increase in their numbers was probably facilitated, in part at least, by this ability to diversify.

A typical chemist's shop of the nineteenth century would, in addition to a wide range of pharmaceutical preparations, stock a selection of toilet articles, tobacco, snuff, tea, coffee, herbs, and other foodstuffs, oils, candles, and dyes. In some cases, the chemist combined with his pharmaceutical enterprises the activities of a grocer, bookseller, insurance agent, tea or lead merchant. J. \& W. Sanderson, druggists of Sheffield (c. 1794-1831), ran a large cutlers and paint and oil business as supplements to their pharmaceutical enterprises. During the second half of the nineteenth century, E. P. Hornby, a successful retail chemist and a prominent member of the Sheffield Branch of the United Society of Chemists and Druggists, launched himself into the manufacture of acids and chemicals, later establishing the Sheffield Chemical Works. ${ }^{21}$ Early in the nineteenth century, G. B. Reinhardt of Wakefield carried on the business of "Chymist, Druggist, Tea-Dealer and British Wine Merchant" from his town centre shop. W. P. Lockwood, chemist and druggist, made extensive use of the Wakefield press during the mid-nineteenth century for advertising purposes, promoting a wide variety of goods, including drugs, pharmaceuticals, and miscellaneous articles connected with the trade, plus a range of cosmetics, hair dyes, perfumes, candles, spices, pickles, sauces, herbs, "Italian goods", and so on. In addition, he acted as agent to a number of insurance companies. J. R. Dore of Huddersfield sold a similar range of domestic goods, including high-quality breakfast teas, mustards, starch, furniture cream, eau-deCologne and the "Huddersfield Bouquet", a "refreshing perfume", priced $1 s$. a bottle. He was also a supplier of Patent Paraffin Oil. Of the nineteen individuals listed as a chemists and druggists in the 1853 Wakefield town directory thirteen were also in business as tea dealers. ${ }^{22}$

A number of individuals combined a chemist's business with other forms of medical activity. In 1854, George Henry Crowther set himself up in business in Wakefield as a chemist and dentist, before devoting himself exclusively to the practice of dentistry. ${ }^{23}$ Other chemists and druggists branched out into medical galvanism, herbalism, phrenology, or midwifery, stocked extensive ranges of surgical appliances or spa waters, or specialized in the concocting and dispensing of homeopathic or botanic preparations, with or without advice. Thomas North Swift of Huddersfield combined the activities of a "druggist and botanist" during the 1860 s and ' 70 s, also acting as agent to Dr Skelton, a well-known local botanic practitioner. The father of Jesse Boot, John, was a follower of Coffinism, calling his Nottingham shop the "British and American Botanic Establishment". He advertised vegetable remedies, both retail and

\footnotetext{
${ }^{21}$ Austen, op. cit., note 10 above, pp. 16, 60 .

22 Wakefield Star, 20 July 1804; Wakefield Journal, 13 December 1850; Wakefield Express, 27 May 1854; Huddersfield Examiner, 23 June 1860; W. White, Directory and gazetteer of Leeds, Bradford, Halifax, Huddersfield, Wakefield and the whole of the clothing districts of Yorkshire, 1853, reprinted Newton Abbot, David \& Charles, 1969.

${ }^{23}$ Wakefield Express, 3 June 1854.
} 


\section{Hilary Marland}

wholesale, and announced he could be consulted at his residence on Mondays, Wednesdays, and Saturdays. ${ }^{24}$ Still others combined the druggist's trade with the compounding of animal remedies and veterinary practice.

Improved opportunities for chemists and druggists to set up in trade can be seen as a natural and expected result of nineteenth-century population growth. On top of this, however, there did seem to be an increased demand by the public for the services which this group could offer. This growing demand is testified to by the fact that the expansion in the number of chemists and druggists greatly exceeded the population growths experienced in Wakefield and Huddersfield during the first half of the nineteenth century (see Table II and Figure I). The poor and labouring classes made up the fastest growing sections of the populations of the two communities, and it was these groups who were most likely to make use of the services of the chemist, or of other fringe elements, rather than the frequently unaffordable qualified medical practitioner.

Table II and Figure I demonstrate how significantly the ratio of chemists and druggists to the township populations of Wakefield and Huddersfield increased during the early- and mid-nineteenth century. In 1821, there was approximately one druggist to every 2,700 inhabitants in Huddersfield. By 1861, the ratio was one druggist to every 1,900 inhabitants. In Wakefield, the ratio rose from one druggist to every 1,800 people to one to every 840 inhabitants between 1821 and 1861 . Wakefield was better served by chemists and druggists throughout the century. But, in both towns, the increase in their numbers outstripped population growth, although there was a levelling off of the ratios in Wakefield after c. 1831. Many of the villages surrounding Wakefield and Huddersfield, especially the larger ones, also had their own chemists' shops. In 1866, the village of Meltham, situated five miles from Huddersfield, had one druggist's shop for its population of 4,046. Horbury, two miles from Wakefield, with only 3,246 inhabitants, supported three druggists' shops in $1866(1: 1082) .{ }^{25}$ Other urban communities also seem to have experienced similar trends: D. Alexander's survey of eight provincial and manufacturing towns-Manchester, Leeds, York, Norwich, Leicester, Bolton, Merthyr and Carlisle-concluded only that by 1850 , there was one chemist's shop to every 1,720 inhabitants. ${ }^{26}$

At the same time as the ratio of chemists and druggists to the population was rising, the ratio of medical practitioners to the populations of Wakefield and Huddersfield was declining. Sigsworth and Swan have suggested that there may be an inverse relationship between the numbers of chemists and druggists and medical practitioners, with the chemists predominating in urban environments during this period. ${ }^{27}$ Their thesis, however, is not completely borne out by the Wakefield and Huddersfield survey. Wakefield, the least urbanized of the two communities, was better served by both medical practitioners and chemists and druggists throughout the century. Wakefield functioned as a market and service town for the region, and the town's

\footnotetext{
${ }^{24}$ Chapman, op. cit., note 5 above, p. 35. See also John V. Pickstone, 'Medical botany (self-help medicine in Victorian England)', Memoirs of the Manchester Literary and Philosophical Society, 1976-1977, 119: 94-95.

${ }^{25} \mathrm{~W}$. White, Directory of Leeds, Bradford, Huddersfield, Halifax, Wakefield, Dewsbury, Sheffield, 1866.

${ }^{26}$ Alexander, op. cit., note 5 above, p. 101.

${ }^{27}$ E. M. Sigsworth and P. Swan, 'Para-medical provision in the West Riding', Bull. Soc. soc. Hist. Med., 1981, 29: 37.
} 
The medical activities of mid-nineteenth-century chemists and druggists

\section{TABLE II. THE RATIO OF CHEMISTS AND DRUGGISTS TO THE POPULATION OF WAKEFIELD AND HUDDERSFIELD, 1790-1871 $\dagger$}

$\begin{array}{ccc} & & \\ \text { Township } & \text { Population } \\ \text { Yakr } & \text { Wakefield } & \text { Huddersfield } \\ 1790 & 8,700 \mathrm{e} & 6,000 \mathrm{e} \\ 1821 & 10,764 & 13,284 \\ 1831 & 12,232 & 19,035 \\ 1841 & 14,754 & 25,068 \\ 1851 & 16,989 & 30,880 \\ 1861 & 17,611 & 34,877 \\ 1871 & 21,076 & 38,654\end{array}$

\begin{tabular}{cc}
\multicolumn{2}{c}{ Number of } \\
Chemists and Druggists \\
Wakefield & Huddersfield \\
2 & 2 \\
6 & 5 \\
$11 \mathrm{E}$ & $7 \mathrm{E}$ \\
14 & 11 \\
15 & 19 \\
21 & 18 \\
18 & 25
\end{tabular}
Ratio of Chemists and Druggists to the Population
Wakefield Huddersfield
$1: 4350 \quad 1: 3000$
$1: 1794 \quad 1: 2657$
$1: 1112 \quad 1: 2719$
$1: 1054 \quad 1: 2279$
$1: 1133 \quad 1: 1625$
$1: 839 \quad 1: 1938$
$1: 1171 \quad 1: 1546$

† The figures for 1871 include both "pharmaceutical chemists" and those individuals who were not included on the pharmaceutical register after 1868 .

e Estimated population

E Estimates derived from trade directory listings for 1828 and 1837.

Sources: Census enumerators' books, Wakefield and Huddersfield Townships, 1841, 1851, 1861, and 1871, and as in Table 1. (The discrepancies between the figures given here and in Table 1 are due to the use of census data in addition to trade directories in Table II.) Population figures taken from W. Page, The Victoria history of the counties of England. A history of the county of York, vol. III, 1913, table of population 1801-71, p. 525.

FIGURE I. THE RATIO OF CHEMISTS AND DRUGGISTS TO THE POPULATION OF WAKEFIELD AND HUDDERSFIELD, 1790-1871.

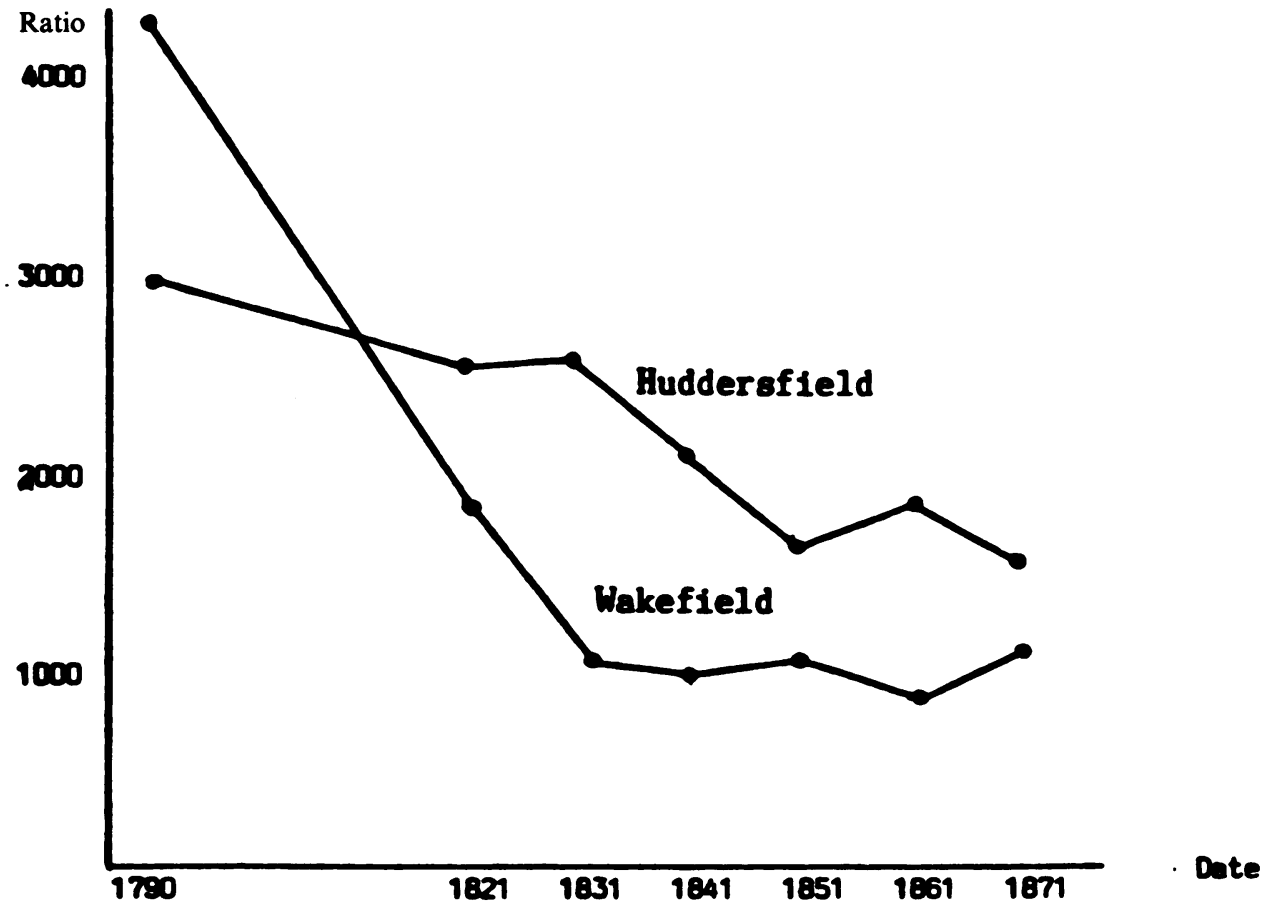

Sources: As for Table II. 


\section{Hilary Marland}

chemists and druggists (and medical practitioners) ${ }^{28}$ may well have provided a service for a wider hinterland compared with Huddersfield. But, as indicated above, many of the villages surrounding both towns had their own chemists' shops, and did not, therefore, necessarily rely on their larger neighbours for their pharmaceutical requirements. There is some indication, however, that as the number of doctors declined in both towns, chemists and druggists stepped in to fill the gap in the market. In 1821 , there was one medical practitioner to every 598 people in the Wakefield Township, while the ratio of chemists and druggists to the population was 1:1794. By 1871 , the ratios were $1: 1240$ and $1: 1171$ respectively. Over the same period, the ratio of medical practitioners to the population of the Huddersfield Township declined from 1:1022 to 1:1841. Meanwhile, the ratio of chemists and druggists to the population increased from 1:2657 to 1:1546 in $1871 .^{29}$

\section{IV}

The significance of the chemist's medical activities, most particularly counterprescribing, is confirmed by the growing concern they aroused amongst contemporaries, especially the group most threatened by these activities, the medical profession. Clearly, nineteenth-century doctors saw some form of overlap between their activities and those of the chemists and druggists, the chemists being serious competitors for custom, and, because, unlike many other fringe groups, chemists were an easily identifiable group, they formed one of the main targets for attacks upon unqualified medical practice. Criticisms of chemists and druggists tended to latch on to the theme that their activities constituted a threat to the population, because of their indiscriminate prescribing and sale of adulterated, even poisonous, articles, but the medical profession were also honest enough to stress their anxieties concerning the chemist's usurpation of the role of qualified medical men. In 1853, a leading article in the Medical Times and Gazette complained, “. . . we reflect, that already the Profession is yearly deprived-we might almost say robbed-of thousands of pounds by pharmaceutists, who prescribe over their counters or even boldly visit patients at their own homes". 30

Much concern was expressed in parliamentary reports about the danger of resorting to chemists and druggists in the case of illness. In 1854, Thomas Gilbert, superintendent registrar for Bristol, stated in his evidence to the Select Committee on medical relief, that many children died without their parents consulting a medical practitioner because "... the difficulty of getting medical aid leads them either to doctor them according to an old Woman's directions, or to take them simply to druggists, who know nothing about the disease, and get them a little quackery". ${ }^{31}$ The particular danger to the public represented by “... persons who have had no

\footnotetext{
28 The question of why smaller and less industrialized urban communities appear to have had more favourable doctor/patient ratios is examined in Marland, op. cit., note 3 above, pp. 258-261. Basically, it is argued that the social make-up of communities and job opportunities better explain the doctor/patient ratios than the size of medical practitioners' catchment areas.

${ }^{29}$ Sources as for Table I and II.

30 'The Pharmaceutical Society and the medical profession', Med. Times Gaz., 1853, 1: 60.

${ }^{31}$ Report from the Select Committee on medical relief, PP, 1854, XII (348), Q. 723. Quoted in Brown, op. cit., note 12 above, p. 298.
} 
professional education as druggists, and acting as oilmen, grocers, or village shopkeepers ...", while at the same time functioning as chemists and druggists, was stressed in the 1864 Report of the Medical Officer of the Privy Council. While unacquainted with the properties of often very powerful drugs, these individuals were free to retail them directly to the public without check or control, and, because of carelessness and ignorance, many serious mistakes were made, leading to illness, poisoning, or death. ${ }^{32}$ Referring to the danger that chemists represented to the populations of large towns, H. W. Rumsey, in evidence to the 1844 Select Committee on medical poor relief, quoted the report of Mr Dorrington of Manchester-"It is perfectly frightful to contemplate the loss of life amongst young children and infants arising from the practice of numerous druggists in the poorer parts of the town". Rumsey claimed that this impression was typical of his returns from forty English towns, adding that ". . . the great bulk of the poorer classes who cannot obtain medical relief in a legitimate way are driven to druggists and unqualified practitioners". In Wakefield, Rumsey stated, “. . . probably from 4,000 to 5,000 poor resort annually to the druggists ..." (approximately one-third of the population). In other communities, the picture was similar. In Southampton, "quite as many of the poor are prescribed for by druggists as by regular practitioners". In Hull, approximately one-quarter of the population were said to utilize the services of the prescribing druggist. ${ }^{33}$

The northern manufacturing towns were pointed to as areas where the practice of resorting to the druggist's shop had reached a peak. A leading article contained in an 1857 issue of the Lancet, for instance, drew attention to the problem of the unqualified practitioner (in which category the druggist was included) in the north.

\begin{abstract}
Such persons exist in numbers which would surprise those less conversant with the real state of the case than ourselves. Hanging about the suburbs of town, infesting its central parts, and acting ostensibly as druggists, these people absorb much money and destroy many lives and much health. But the north is the favoured habitat of such individuals; and more especially the manufacturing districts of Lancashire and Yorkshire. ${ }^{34}$
\end{abstract}

G. Wilson, a Leeds surgeon, describing the extent of unqualified practice in his district, complained in a letter to the Lancet in 1854, that the "lower extreme" of a surgeon's potential practice was effectively closed to him by the prescribing druggists.

\footnotetext{
These people sell to the working class for a few pence whatever to themselves seems fit and proper for all manner of diseases, never leaving their crowded shops, and of course living at no expense for horse, carriage, \&c, while all their receipts are in ready money. But when the patient has spent all his ready cash, what then? Why he goes to the regular practitioner, where he gets credit for months, years, or very frequently for ever [his emphasis]. ${ }^{35}$
}

For the poorer classes, the druggist served not only as a supplier of medicines and advice, but in some cases as dentist, accoucheur, and surgeon. To cite Rumsey again, in Lincoln "... the retail druggists have considerable practice among the poor, both in

\footnotetext{
${ }^{32}$ Sixth Report of the Medical Officer of the Privy Council, PP, 1864, XXVIII I (3416), App. 16, 743-752.

${ }^{33}$ Report from the Select Committee on medical poor relief. 3rd Report, PP, 1844, IX (531), Evidence of H. W. Rumsey, Esq., p. 546, Q. 9121.

${ }^{34}$ Lancet, 1857 , ii: 326.

35 Ibid., 1854, i: 458.
} 


\section{Hilary Marland}

chronic cases and in the early stage of acute complaints; minor operations are also performed by them". It was common practice for chemists and druggists to treat patients in the early stages of a disease, and in Brighton, for example, this group was said to treat the same number of persons as the hospital, dispensary, and medical clubs together. ${ }^{36}$ It has also been suggested that many women of the poorer classes resorted to a "sixpenny doctor", often a druggist, during their confinements. Smith estimates that this service cost between $3 s$. and $7 s .6 d$. (frequently paid by instalments), the price remaining stable throughout the nineteenth century. ${ }^{37}$

It appears likely that the poor and working classes frequently combined the services offered by a druggist (or by other fringe practitioners) with attendance at a local infirmary or dispensary, or with treatment by a regular medical man. A scene in Mary Barton, which describes working-class life in mid-nineteenth-century Manchester, may well have been typical. In Elizabeth Gaskell's novel, John Barton goes to a druggist for medical assistance on behalf of a workmate stricken with typhus fever, prior to attempting to obtain an infirmary order. Barton described the case to the druggist, who “... proceeded to make up a bottle of medicine, sweet spirits of nitre, or some such innocent potion, very good for slight colds, but utterly powerless to stop, for an instance the raging fever of the poor man it was intended to relieve". However, "... Barton left the shop with comfortable faith in the physic given him; for men of his class, if they believe in physic at all, believe that every description is equally efficacious". The following day, Barton's friend, Wilson, attempted, without success, to obtain an order from a local millowner for the admittance of the sick man to the fever wards of the local infirmary. The man died shortly afterwards.$^{38}$ Dispensaries and, more particularly, infirmaries were incapable of admitting all applicants for treatment-complaints relating to a shortage of facilities and finance were common to all such institutions during the nineteenth century-and frequently excluded certain medical and social categories, including fever, chronic and obstetric cases, and children. Presumably, these factors drove many individuals to seek fringe sources of relief, including the services of the chemist and druggist.

In 1857 a Lancet editorial, which attempted to analyse the popularity of fringe practice in the manufacturing districts, explained that:

Large towns consist almost entirely of operatives who look upon physic as a trade,-and a poor one too,-who have not the ability to form any opinion as to the proficiency of their betters in point of general education - who rather like some one of their own class - who have a strong belief in a natural gift for doctoring, and, above all, believe most fervently in cheap physic, cheap advice, and cheap visits. ${ }^{39}$

Rumsey, meanwhile, claimed that the difficulties of obtaining proper medical advice induced "the multitude" to flock to the druggist's shop.

${ }^{36}$ Report from the Select Committee on medical poor relief, 1844, op. cit., note 33 above, p. 547, Q. 9121.

${ }^{37}$ F. B. Smith, The people's health 1830-1910, London, Croom Helm, 1979, pp. 40-41.

38 Elizabeth Gaskell, Mary Barton. A tale of Manchester life, 1st pub. 1848, Penguin ed., 1970, pp. 101-109.

${ }^{39}$ Lancet, 1857, ii: 326. 


\section{The medical activities of mid-nineteenth-century chemists and druggists}

I do not say it is the only cause; the ignorant and uninformed have a natural tendency to seek benefits of all kinds from inferior sources. Then the easy access to the druggist's shop, vying with the gin palace in its tempting decorations, attracts those who prefer spending a few pence, to encountering the formalities and delay attendant on an application to a qualified practitioner. Then the speedy apprehension of the case by the druggist's shopman, a glance being sufficient to satisfy him both as to its nature and treatment, and his ready selection of some drug as a certain cure for the malady of the customer, all this tells wonderfully on the ignorant of all classes. The inevitable results to the community are fearful loss of life and destruction of health. ${ }^{40}$

The practice of resorting to the fringe practitioner or the druggist's shop was not confined to the poor. The middle and even upper classes seem to have shared to some extent in the desire to keep doctors' bills to a minimum, in a faith in the possibilities of fringe remedies, and in the practice of shopping around for medical care. G. Wilson, the Leeds surgeon cited above, emphasized that many of the middle class resorted first to the druggist's shop when taken ill, remarking caustically, "Nor is the druggist system confined to the poor, for very many indeed of the middle classes go to the druggist first, and only send for the surgeon when a certificate of the cause of death seems likely to be wanted for the registrar."41

The biographies of Charles Waterton, the naturalist and squire of Walton Hall, near Wakefield, illustrate how one nineteenth-century gentleman, albeit a highly eccentric one, dosed himself with such potions as laudanum, calomel, jalep, and sulphate of quinine. Waterton developed his own prescriptions, and "Mr Waterton's Pills" were famous throughout the neighbourhood. Presumably the ingredients for such remedies were procured from a local chemist's shop. ${ }^{42}$

Both rich and poor utilized the druggist's services for the compounding of family or homely recipes. Those who could afford them stocked up with family medicine chests, containing well-tried remedies for common complaints. Again, local reminiscences point to the continuing popularity of self-medication, many of the remedies described using natural ingredients, including plant extracts and herbs, and rather more curious components, for example, dung of cat and dragon's blood; others making use of simple medicaments, obtainable from all chemists and druggists. For example, the recipe book of James Woodhead of Netherthong, near Huddersfield, written around 1818 and containing approximately forty remedies, recommended oil of cloves for toothache, spirits of turpentine and castor oil for obstructions of the "testines", and turmeric for liver complaints. The booklet also contained a recipe for "female pills", composed of iron, aloes, and antimony. ${ }^{43}$ More generally, the continuing popularity of such self-help manuals as Wesley's Primitive physic and Buchan's Domestic medicine, ${ }^{44}$ and large numbers of lesser-known works, illustrates the widespread use of self-help

\footnotetext{
${ }^{40}$ Report from the Select Committee on medical poor relief, 1844, op. cit., note 33 above, p. 547, Q. 9121.

${ }^{41}$ Lancet, 1854, i: 458.

42 R. Aldington, The strange life of Charles Waterton 1782-1865, London, Evans Brothers, 1949; R. A. Irwin (editor), Letters of Charles Waterton, of Walton Hall, near Wakefield, London, Rockcliffe, 1955; G. Phelps, Squire Waterton, Wakefield, EP Publishers, 1976; Edith Sitwell, The English eccentrics, London, Faber \& Faber, 1933.

${ }_{43}$ James Woodhead, Netherthong, recipe book, 1818, MS, Kirklees District Archives (KC 190/1).

44 The success of William Buchan's Domestic medicine; or the family physician, first produced in 1769, was immediate and great: nineteen large editions, amounting to at least 80,000 copies, were sold in the author's lifetime alone (1729-1805). For the background to Buchan's work, see C. J. Lawrence, 'William Buchan: medicine laid open', Med. Hist., 1975, 19: 20-35.
} 


\section{Hilary Marland}

medicine. While many of the self-help manuals concentrated on regimen and prevention, homely remedies frequently attempted to effect a cure. ${ }^{45}$ Just how widespread the use of homely remedies was is demonstrated by the frequency with which chemists advertised their skills in making up such prescriptions, particularly in the local press. In 1804, for example, G. B. Reinhardt, a Wakefield druggist, promised that

Those families who may honor [sic] him with their Commands, may depend upon having every Article in the Medical Department, as Genuine as at the Apothecary's Hall, London; and that his most anxious Care and Attention will be exerted to the preparation of Physicians Prescriptions, and all other medical recipes [my italics]. ${ }^{46}$

Advertisements of this nature remained common throughout the nineteenth century. In 1818, for example, William Tee of Wakefield guaranteed accuracy in the making up of family recipes; and in $1839, \mathrm{G}$. Hackforth announced to the Wakefield public that he had taken additional premises in Kirkgate, which he intended to open as “A Family Medicine Warehouse and General Drug Dispensary". In 1855, John Handley, also of Wakefield, a member of the Pharmaceutical Society of Great Britain, promised those who would entrust him with their prescriptions and family recipes that they would be carefully compounded under his own superintendence, using the best quality articles. ${ }^{47}$ Compounding family remedies made up a crucial part of the chemists' business throughout the century. Judging by the way it was emphasized in their advertisements, it was probably a far more important component of their trade than the making up of doctors' prescriptions.

With few restrictions on the sale of drugs, chemists (and other retail groups) were able to sell their medical wares unimpeded for much of the nineteenth century. One of the best illustrations of the involvement of chemists in the retail of drugs directly to the public is the massive over-the-counter sale of opium preparations. ${ }^{48}$ Opium and a wide range of patent cures and infant calmatives containing opiates were easily obtainable and inexpensive, and their widespread usage, in particular their administration to young children, was a cause of great concern to the medical profession, parliament, and the interested layman. Again, the practice was said to be particularly widespread in the northern manufacturing districts. Opiates were widely obtainable from chemists' shops, including the most respectable establishments, and from many other retail outlets. Chemists frequently made up their own preparations, and these, together with patented nostrums, were said to be sold "by the gallon" in the manufacturing districts.

\footnotetext{
45 For self-help medicine, see the essays contained in Roy Porter (editor), Patients and practitioners. Lay perceptions of medicine in pre-industrial society, Cambridge University Press, 1985, especially Ginnie Smith, 'Prescribing the rules of health: self-help and advice in the late eighteenth century', and Roy Porter, 'Laymen, doctors and medical knowledge in the eighteenth century: the evidence of the Gentleman's Magazine'.

46 Wakefield Star, 20 July 1804.

47 Wakefield and Halifax Journal, 10 July 1818; Wakefield Journal, 4 January 1839; Wakefield Express, 7 April 1855.

${ }^{48}$ See V. Berridge and G. Edwards, Opium and the people, London, Allen Lane/St. Martin's Press, 1981; V. Berridge, 'Opium over the counter in nineteenth century England', Pharm. in Hist., 1978, 20: 91-100; J. Ginswick (editor), Labour and the poor man in England and Wales 1849-1851, vol. I, London, Frank Cass, 1983, pp. 47-56, 194-195. For the doping of infants with opiates, see M. Hewitt, Wives and mothers in Victorian industry, London, Rockliffe, 1985, ch. 10.
} 


\section{The medical activities of mid-nineteenth-century chemists and druggists}

George Hawksworth, a Sheffield druggist, for example, was noted during the first half of the nineteenth century for his "Buff" or "Hawksworth's Mixture", which was composed of rhubarb, magnesia, aromatics, and opium, a favourite children's mixture. ${ }^{49}$ In 1845, Dr Lyon Playfair described how far the practice of purchasing opium preparations had extended amongst the working classes of Lancashire. In Ashton-under-Lyne, narcotic drugs were vended by all the druggists' shops. Three druggists in one district of Manchester, “. . . all of acknowledged respectablity", sold a total of nine gallons of laudanum weekly. A surgeon based in Wigan, who also kept a druggist's shop, certified to Playfair "... that he is in the habit of selling various preparations of opium under the forms of infants' mixture, Godfrey's cordial, paregoric elixirs, and laudanum; also, crude opium, combined with other substances, according to popular recipes". ${ }^{50}$ In Wakefield and Huddersfield, vast quantities of Godfrey's Cordial, Atkinson's Infant Preservative, Peace and Steedman's Soothing Powders for Children, plus preparations of the suppliers' or customers' own creation, were sold by chemists and other retailers, in addition to crude opium and laudanum. In 1843, Dr Wright of Wakefield, honorary physician to the West Riding County Lunatic Asylum and Wakefield House of Recovery, claimed that opium preparations, notably "soothing syrups", were prepared wholesale by most druggists in the town, "... several hundred pounds weight of these pernicious compounds" being sold annually, " . . besides the stamped medicines of similar effect". ${ }^{51}$

Birth control and the procurement of abortions were two further, closely related, categories of medical care, where self-medication and the assistance of fringe or folk elements were much resorted to, and which were also much criticized by contemporaries. Chemists and druggists were major suppliers of both abortifacients and birth control appliances. A wide variety of herbs and drugs were widely and cheaply available, including tansy, pennyroyal, gin and salts, iron and aloes, caraway seeds, turpentine, quinine, and, later in the century, lead. Quinine, for example, was widely used as both a spermicide and to induce abortion. Chemists and druggists also acted as suppliers of a wide range of "French" or "female" pills, which were advertised as curing "suppression of the menses" and "female irregularities", preparations such as "Velnos Vegetable Syrup", "Widow Welch's Pills", and "Frampton's Pills of Health" ${ }^{52}$ Techniques of birth control and abortion were more accessible in areas where industrial employment was available to women, and where it was possible to

\footnotetext{
49 Austen, op. cit., note 10 above, pp. 20-21.

${ }^{50}$ Second Report of the Commissioners for inquiring into the state of large towns and populous districts, PP, 1845, XVIII (610), App., part II, Dr L.. Playfair, Report on the sanatory [sic] condition of the large towns in Lancashire, pp. 77, 62, 65.

${ }^{51}$ T. G. Wright, MD, A lecture on quack medicines, delivered to the Wakefield Mechanics' Institution, Feb. 20th, 1843, London, R. Groombridge, Simkin, Marshall, 1843, p. 26.

52 While there is little doubt that abortifacients were sold by druggists, this does not necessarily mean that they were sold with the intention of procuring an abortion. Hefty doses of these substances would be required to produce this effect. Nor were these preparations, particularly those containing iron, necessarily purchased with the intention of producing an abortion. They were frequently taken to remove "menstrual obstructions", used in effect in a similar way to other popular nineteenth-century purgatives, and regular medical practitioners frequently used iron-based and purgative preparations for the treatment of amenorrhoea and chlorosis. See, P. S. Brown 'Female pills and the reputation of iron as an abortifacient', Med. Hist., 1977, 21: 291-304.
} 


\section{Hilary Marland}

obtain information and remedies, typically urban, industrial areas, as represented by Wakefield and Huddersfield. Frampton's Pill of Health, for example, was widely advertised in the two towns, and, indeed, throughout the West Riding, during the mid-nineteenth century, claiming to remove "all Obstructions in females". In 1839, it was offered for sale by a long list of retailers, including England and Fell, chemists of Huddersfield, six Wakefield chemists and druggists, five Halifax chemists, and twelve Leeds chemists; presumably the actual number of stockists was very much higher. ${ }^{53}$

During the nineteenth century, chemists and druggists made extensive use of advertising to promote sales. This coincided to a certain extent with a fall-off in the number of "pedlar-druggists", and their replacement on the one hand by itinerant quacks and medicine vendors, and on the other by shopkeeping chemists and druggists. During the nineteenth century, the practice of individuals such as Ralph Hodgkinson of Sheffield, who kept a shop in King Street between 1775 and 1792, travelling to nearby towns and villages on market days, where he traded successfully in ancient remedies, became far less common. ${ }^{54}$ Increased publicity for the shopkeeping druggist during the nineteenth century was largely achieved through the distribution of trade cards and via the medium of the local press. Newspaper advertisements were aimed in part at the local medical profession, guaranteeing accuracy in the compounding of prescriptions and in the quality of drugs. But the general public formed a far more important target of advertising campaigns. On setting up as a chemist and druggist in Sheffield in 1807, for example, Joshua Gillat solicited "... the favour of the public which he will endeavour always to merit by serving his friends in the best manner and on the lowest terms. Prescriptions made up with the greatest care, accuracy and neatness". ${ }^{55}$ When W. Clater commenced business in Wakefield in 1827, he placed the following advertisement in the Wakefield and Halifax Journal:

\section{W. Clater \\ Chemist and Druggist \\ Market Place, Wakefield}

Respectfully informs the Nobility, Gentry, and Inhabitants of Wakefield, and its Vicinity, that he has commenced Business in the above place, and has laid in an entire, fresh, and extensive Assortment of all kinds of Drugs, Chemicals, and Galenicals [my italics]. ${ }^{56}$

In 1860, Charles Spivey of Huddersfield retired from his chemist's business, returning thanks, not to the medical profession, but ". . . to the Inhabitants of Huddersfield and neighbourhood for their liberal support during the many years he has been amongst them, ...". He recommended that continued support should be given to his successor in business. ${ }^{57}$

\footnotetext{
${ }^{53}$ Leeds Mercury, 8 June 1839. For abortion as a form of birth control in the manufacturing districts, see P. Knight, 'Women and abortion in Victorian and Edwardian England' and A. McLaren, 'Women's work and the regulation of family size: the question of abortion in the nineteenth century', Hist. Workshop, 1977, 4: $57-68,70-81$.

${ }^{54}$ M. C. Hamilton, 'The development of medicine in the Sheffield region up to 1815', Sheffield University MA thesis, 1957, p. 53.

${ }_{55}^{5}$ Sheffield Iris, 23 February 1807. Quoted in Austen, op. cit., note 10 above, pp. 21-22.

56 Wakefield and Halifax Journal, 19 January 1827.

${ }^{57}$ Huddersfield Examiner, 28 July 1860.
} 


\section{The medical activities of mid-nineteenth-century chemists and druggists}

Chemists and druggists employed intensive sales drives, most specifically to encourage an increased turnover of patent medicines and their own special lines and preparations. Many famous brand names were first manufactured in the back rooms of chemists' shops, such as "Nurse Harvey's Gripe Mixture", formulated by Arthur Oglesby, a Barnsley chemist and druggist; and "Kompo", orginally known as "White's Composition Essence", and manufactured by a Leeds chemist and herbalist. ${ }^{58}$ On a more local level, in 1810, R. Elliot of Huddersfield, "Chemist and Apothecary", "strongly recommended to the Public" a selection of his "valuable medicines, Elliot's Restorative and Healing Tincture, Elliot's Family Cordial, The Ceylonian Powder, and Elliot's Lozenges". 59 During the 1832 cholera epidemic, John Moss, druggist of Sheffield, sold his "cholera pill" as a preventive. It gained a wide reputation, as did his linseed and mustard poultice for feet, and embrocation of camphor spirit for the stomach.$^{60}$ In the 1870 s, William T. Bygott, dispensing chemist of Huddersfield, promised that his Toothache Elixir would cure toothache or tic-doloreux in just one minute, for only $1 s$. $1 d$. or $2 s .9 d$. a bottle. ${ }^{61}$ The sale of special preparations did lead to a certain amount of rivalry and imitation. In the 1873 Huddersfield directory, for example, T. N. Swift advertised his own "Original Swift's Specific", a "never failing remedy" for gout, rheumatism, lumbago, sciatica, and all nervous affections, prepared only by $\mathrm{T}$. N. Swift. In the same publication, R. Cuthbert, dispensing and family chemist, advertised his "Flockton's Swift's Specific", also for gout, rheumatism, lumbago, etc., prepared only by R. Cuthbert! ${ }^{62}$

Upon retirement or death the chemist and druggists's collection of prescriptions and recipes were handed over to his heirs or successors in business, as in 1832, when G. B. Reinhardt, chemist and druggist, took over the shop of his late father, situated near the old church, Wakefield. He promised that business would continue as usual in the same premises,

\footnotetext{
... whereat may be had, as usual, faithfully prepared from the Recipes of the late G. B. Reinhardt, his invaluable Medicine, BALSAM of HOREHOUND, for curing Coughs, Colds, Asthmas, Hooping Cough, Declines, and Consumptions. Also [opportunely in this particular year] his truly valuable and never failing Medicine for the Cholera Morbus, or Vomiting and Purging; and also his excellent medicines for Worms; all of which Medicines, from trial and experience, have obtained very high reputations, and can only be prepared by G. B. Reinhardt, as he is the sole possessor of his late Father's Recipes. ${ }^{63}$
}

In 1870 , W. P. England \& Co. transferred their large retail business to J. R. Dore, "pharmaceutical chemist", and in so doing "... handed to him all their private formulae, receipts and copies of prescriptions, who may be fully relied on for accurately dispensing them". ${ }^{64}$ The technique of passing on recipes ensured not only secrecy and exclusivity, but may also have encouraged expertise, the building up of knowledge, and the preservation of tried and tested remedies.

\footnotetext{
${ }^{58}$ A. Wright, 'Some Yorkshire proprietaries', Pharm. Hist., 1980, 10: 6-8.

${ }^{59}$ Wakefield Star, 2 February 1810.

${ }^{60}$ Austen, op. cit., note 10 above, pp. $27-28$.

${ }^{61}$ Huddersfield Examiner, 1 January 1870.

${ }^{62}$ Huddersfield directory and year book 1873, Huddersfield, George Harper, 1873.

${ }^{63}$ Wakefield and Halifax Journal, 16 November 1832.

${ }^{64}$ Huddersfield Examiner, 17 September 1870.
} 


\section{Hilary Marland}

Chemists and druggists were probably amongst the largest suppliers of patent medicines during the nineteenth century, although they faced much competition in this field. ${ }^{65}$ Most stocked vast ranges. For example, during the mid-nineteenth century, W. P. England of Huddersfield and F. Cardwell of Wakefield, both well-established chemists, included Brande's Bronchial Sedative, Woolley's Pectoral Candy, Dr Locock's Pulmonic Wafers, Holloway's Ointment, and Dr Bright's Pills of Health for both sexes amongst their stock. Many chemists also claimed exclusive rights to market certain products. During the 1830s, W. P. England and Taylor and Birch of Huddersfield acted as exclusive suppliers of Concentrated Compound Decoction, prepared by Moxon and Smith, chemists of Hull. ${ }^{66}$ In 1839, R. S. Alderton of Wakefield and C. Spivey of Huddersfield were appointed sole agents for the retail of Martin Sweeting's Toothache Elixir. ${ }^{67}$ During the same year, Mr Smith informed the afflicted of Wakefield,

... Mrs. HAIGH has appointed him to sell her valuable Ointment, which will be found very efficacious in the following Diseases, viz.- Relief in Cancers, Abscesses, Bad Breasts, Swelling and Tumour, Wounds, Ulcers, etc. etc. ... The Proprietor of the above Ointment being well aware of its unrivalled efficacy, wishes it to be made generally known The Ointment may also be had at her residence, in the Little Bull Yard, Westgate, Wakefield. ${ }^{68}$

Chemists and druggists, however, did not enjoy anything like a complete monopoly in the retailing of medicines and patent preparations (nor do they today, when many medicines are sold in supermarkets and other retail outlets). There was competition for custom not only between the regulars and the fringe, but also between the various components of the fringe. The chemist and druggist faced competition from quack doctors and patent medicine vendors, unrestricted in their methods of sale by any attempts to enforce codes of professionalism or practice. The unqualified medical practitioner found it to his advantage to term himself a "chemist and druggist"-by so doing, he avoided prosecution for practising without a licence. Indeed, the complaints of chemists and druggists about their fringe rivals were similar in tone to those of regular doctors concerning the competition of the unqualified. As the Pharmaceutical Journal grumbled in 1846,

... as the law now stands every man who has a 'doctor's shop', with coloured bottles, is a Chemist and Druggist. The itinerant quack doctors ... are, according to law, Chemists and Druggists. Although they periodically frequent the markets, they have Druggist's shops, and enjoy the same legal privileges as a Member of the Pharmaceutical Society. ${ }^{69}$

The public could obtain drugs and patent preparations from a variety of other retailers: stationers, newspaper proprietors, grocers, butchers, hairdressers, and publicans, to name but a few. The corner shop, situated typically in the poorest areas of

\footnotetext{
${ }^{65}$ In a survey of the retail of patent medicines in Bath between 1744 and 1800, prior to the expansion in the number of chemists and druggists, P. S. Brown sampled 108 proprietors or manufacturers. Out of this total, half were identified, 13 dentists, 12 surgeons, 11 practitioners of physic, 11 apothecaries, 10 chemists and druggists, and two clergymen. P. S. Brown, 'Medicines advertised in eighteenth-century Bath newspapers', Med. Hist, 1976, 20: 152.

${ }^{66}$ Halifax and Huddersfield Express, 2 April 1831.

${ }^{67}$ Leeds Mercury, 1 June 1839.

68 Wakefield Journal, 17 May 1839.

${ }^{69}$ Pharm. J. \& Trans., 1845-46, 5: 193. Quoted in Crellin, 'The growth of professionalism', op. cit., note 4 above, p. 223.
} 
town, also sold drugs and patent medicines, and was much resorted to by a predominantly working-class clientèle. Booksellers, stationers, printers, and newspaper proprietors, with their easy access to advertising facilities, were also major suppliers of patent medicines. The Hurst family of Wakefield, for instance, booksellers, stationers, printers and proprietors of the Wakefield and Halifax Journal, advertised and sold a vast selection of patent remedies to their readers. Just one issue in January 1827 advertised for sale at the Journal office Butler's Acidulated Cayenne Lozenges, Butler's Pectoral Elixir, Perry's Essence, Solomon's Drops, Mr. Lignum's Improved Vegetable Lotion, Marshall's Universal curate, and so on. ${ }^{70} \mathrm{~A}$ more unlikely stockist of patent medicines was Mr Hollingshead, a Huddersfield draper, who acted as agent for the sale of John Kaye's Worsdall Pills, “... the most extensively established Family Medicine of the present day". Worsdall's Pills were supplied in other Yorkshire towns during the 1840 s by a variety of shopkeepers, including booksellers, grocers, tailors, and hairdressers. ${ }^{71}$ This large group of nonpharmaceutical medicine suppliers was seen, not surprisingly, as a major threat by chemists and druggists. However, the chemists' own lack of specialization led to difficulties in eliminating competition from other retail groups and itinerant hawkers of medicines. The Pharmaceutical Journal stated in 1843:

\begin{abstract}
The indiscriminate sale of drugs by unqualified persons would produce much less injury to the credit and interests of the regular Druggists, if the public had the means of forming a correct estimate of the value of the articles they purchase, and of the qualifications of the parties concerned. But unfortunately in most country towns not only is every Grocer or Oilman a Druggist, but almost every Druggist is a Grocer or Oilman. The Druggist had no badge or credentials to designate his superior qualification: in fact, he is not of necessity more qualified than the Grocer. The blue and red bottles in the windows are common to all; and this is the criterion understood by the public as indicating what is called 'a doctor's shop' [italics in original]. ${ }^{72}$
\end{abstract}

\title{
$\mathbf{V}$
}

Despite competition from other fringe groups and medicine suppliers, and, indeed, the "competition" of the regular medical profession, chemists and druggists increased their numbers during the nineteenth century, particularly in rapidly urbanizing communities. Many were able to make decent, even excellent, livings. Towards the top end of the scale were individuals such as George Hall of Huddersfield, who, during the nineteenth century, ran a highly successful business from his shop in Kirkgate. In 1851, then aged forty, Hall employed two general servants and one journeyman in his shop; three apprentices were bound to him. Hall resided out of town, at Longwood House in the prosperous suburb of Fartown, where, in 1851, he farmed twenty-eight acres; in 1861 , ninety-two acres, apparently acquired from profits of his pharmaceutical enterprises. He employed five labourers on his land and two domestic servants. ${ }^{73}$ Hall was a committee member of the Huddersfield Infirmary, which he also supplied with drugs, and a member of the Town Council.

70 Wakefield and Halifax Journal, 12 January 1827.

71 William's directory of the Borough of Huddersfield, London, J. Williams, 1845.

72 Pharm. J. \& Trans., 1843-44, 3: 101. Quoted in Crellin, 'The growth of professionalism', op. cit., note 4 above, p. 222.

${ }^{73}$ Census enumerators' books, Huddersfield Township, 1851 and 1861. 


\section{Hilary Marland}

While few achieved this kind of success, by the second half of the century, many chemists and druggists were able to demonstrate their increased prosperity by abandoning the practice of living over the shop, choosing to reside in the new suburbs and out-townships. By 1861, half of the eighteen chemists and druggists in business in Huddersfield had residences separate from their workplaces. ${ }^{74}$ Increased employment of both domestic servants and shop assistants also points to rising prosperity. By 1851 , approximately two-thirds of chemists and druggists in both Wakefield and Huddersfield employed domestic servants. ${ }^{75}$ A further indicator of success was the trend towards the opening of branch establishments or chains in the second half of the nineteenth century. By 1884, for instance, Needham Bros., "medical chemists", owned three shops, one in Buxton Road in the centre of Huddersfield, the others in the nearby villages of Lindley and Meltham. ${ }^{76}$ In addition to improving their economic status, many chemists and druggists achieved a high social standing in their communities, participating in local politics and voluntary societies, individuals such as Mr William King, ". . . a figure well known and held in high esteem in the life of Huddersfield". Following an apprenticeship in Hull, King came to Huddersfield in 1857, entering the business of Henry Fryer, first as assistant, then partner. After the death of Fryer, King took over his shop, with some success. King was for many years local secretary of the Pharmaceutical Society, and was active in the Infirmary and many church societies. ${ }^{77}$ Thomas Gissing, a Wakefield chemist and the father of the novelist George Gissing, participated in local Liberal politics and the Mechanics' Institute, his special interests being botany and poetry. He also was active in the Wakefield Town Mission. Although Thomas Gissing was reputed to have "bourgeois pretensions", when he died in 1870, his family were left in poverty, and the Westgate business sold. ${ }^{78}$

Chemists and druggists continued, throughout the nineteenth century, to involve themselves in a wide variety of medical activities - the sale of the ingredients of remedies, the concocting of their own prescriptions and popular recipes, the vending of patent medicines, advising, and, in some cases, home visiting, surgical practice, dentistry, and midwifery. Counter-prescribing and advising, which seem to have been the most widespread non-retailing activities to be undertaken by chemists, were perhaps seen by the medical profession as the most serious infringements of the rights and prerogatives of regular practitioners, and as an overstepping of those of the chemist. However, chemists and druggists, by virtue of their status as often highly respectable tradesmen, and because of their growing usefulness as medicine suppliers and expertise in the making up of doctors' prescriptions, were protected to some extent from the attacks of the medical profession upon fringe practices and practitioners.

Counter-prescribing was very closely linked to the chemist's selling activities, and it seems reasonable that a chemist should have offered advice together with a medication,

\footnotetext{
${ }^{74} \mathrm{~W}$. White, Directory and topography of the Borough of Leeds, Wakefield, Bradford, Huddersfield, etc., Sheffield, 1861.

${ }^{75}$ Census enumerators' books, Wakefield and Huddersfield Townships, 1851.

${ }^{76}$ Huddersfield Weekly Examiner, 26 July 1884.

${ }^{77}$ Huddersfield Weekly Chronicle, 14 November 1914. For one of the few, albeit brief, discussions of the status of chemists and druggists, see Crellin, 'Leicester and 19th century provincial pharmacy', op. cit., note 4 above, pp. $417-420$.

78 J. Halperin, Gissing. A Life in books, Oxford University Press, 1982, pp. 12-14; G. Tindall, The born exile. George Gissing, London, Maurice Temple Smith, 1974, pp. 48-49.
} 


\section{The medical activities of mid-nineteenth-century chemists and druggists}

especially as a large proportion of his clientèle would have been incapable even of reading the instructions on a packet or medicine bottle. Also, it seems to have been expected that a chemist would offer advice. In particular, it appears that the poor were frequently dependent upon the advice of their local chemist, in the absence of alternative sources of medical assistance. As Jacob Bell pointed out, the chemist "... cannot avoid occasionally giving advice, without incurring the imputation of ignorance and losing the confidence of his customers. . ." ${ }^{79}$ Moreover, chemists and druggists seem to have believed that they had a right to practise in this way, and it should be stressed that counter-prescribing and advising were carried out by all chemists, whether they were members of the Pharmaceutical Society or not, and whatever their economic and social standing, although more "respectable" chemists and druggists were less likely to have indulged in such activities as dentistry, midwifery, and home visiting. Jacob Bell, an articulate representative of the more respectable and substantial members of this group, was well aware of the fact that chemists and druggists dispensed much advice as well as medicine. And individuals such as William Valentine Radley of Sheffield, a founder and a member of the Council of the Pharmaceutical Society of Great Britain and first secretary of the Sheffield Branch, contended that while no chemist had the right to call himself a "medical man", members of the trade should be free to attend to small ailments over the counter. ${ }^{80}$

Chemists and druggists responded in a timely way to changing market conditions during the nineteenth century. After 1850 , purchasing power rose considerably, a result of a growth in the number of consumers and the increasing overall affluence of these consumers. The consumption of medicines, always large, was given a further boost by this development. Meanwhile, the growth in urban populations led to changes in the provision of medical care on a self-help basis. Access to herbal remedies and rural-based folk healers probably diminished, and the rising urban populace was forced to turn more frequently to retail outlets for the supply of medicines and advice. The "retailing revolution" of the nineteenth century witnessed the emergence of wholesalers, price competition, extensive advertising, window displays, cash sales, and the spread of shops, especially those catering for working-class consumers. Chemists and druggists were amongst the first retail groups to take advantage of this revolution, coming to make extensive use of newspaper advertisements for the publicizing of their services (also benefiting from a further expansion in provincial newpapers during the nineteenth century), developing modern and competitive retailing techniques, basing themselves in central locations, setting up attractive window displays, and offering customers competitive prices and special offers. Medicines and medical advice came to be seen as commodities, to be bought and bargained for, and this is perhaps best exemplified by the massive growth in the production and purchase of patent medicines during the latter decades of the nineteenth century, retailed without expertise or knowledge of the product. ${ }^{81}$ The pharmaceutical business came to accommodate diverse retail groups, and by the second half of the century, prosperous, well-trained and highly respectable individuals, members of the Pharmaceutical Society, could

\footnotetext{
79 Jacob Bell, A concise historical sketch of the progress of pharmacy in Great Britain, London, John Churchill, 1843, p. 90. Quoted in Brown, op. cit., note 12 above, p. 312.

${ }^{80}$ Austen, op. cit., note 10 above, pp. 44-45.
} 


\section{Hilary Marland}

share the label "chemist and druggist" with small-time traders and general dealers.

While many chemists and druggists underwent limited or no training, and had little skill in their trade, entry into the higher echelons of the chemist's business demanded extensive knowledge, acquired through a long period of apprenticeship, which by the first half of the nineteenth century could cost as much as $£ 200$ for a five-year term. ${ }^{82}$ Many trainees went on to further their pharmaceutical education while acting as assistants or managers to established druggists; others attended the specialized training courses set up after 1842 under the auspices of the Pharmaceutical Society. Undoubtably, some chemists gained expertise not only in pharmacy, but also, through practical experience and informal training, in prescribing and advising. J. R. Dore of Huddersfield, for example, when opening his shop in New Street in 1860, stated, as a guarantee of his competence, that he had passed the major examinations of the Royal Pharmaceutical Society in Latin, Chemistry, Botany, Toxicology, Materia Medica, etc. He had also had many years' experience in some of the "best establishments" in southern England. Dore vowed to gain his share of public support by close personal attention to the business, by keeping articles of only the very best kind, and by moderate charges. (He added that all poisons were kept in a distant part of the shop, thus lessening the danger of mistakes! $)^{83}$

Already by the mid-and certainly by the late-nineteenth century, many chemists and druggists could capitalize on claims of familiarity and continuity. In Wakefield and Huddersfield at least, many of the shops that were trading successfully at the end of the nineteenth century dated from the early decades of the century. A number of pharmaceutical businesses were family concerns, and these tended to be the most enduring and prosperous. For example, the Fell family of Huddersfield were involved in the druggist's trade from the 1820s onwards, when they owned two shops, John in King Street, and his brother, Jacob, in the Market Place. By 1851, while Jacob still had his Market Place business, Robert Fell had taken over his late father's shop in King Street. Meanwhile, Robert's brother, William, had also set up shop in the well-to-do Belgrave Terrace, where he lived with his mother, a gentlewoman and proprietress of houses. As late as 1881, Robert Fell was still in business in King Street. ${ }^{84}$ The Fells were exceptional both in the number of family members involved in the trade-three shops were owned by them in 1851-and in their prosperity. But it was not unusual for a business to pass through several generations during the nineteenth century.

\footnotetext{
81 The value of patent medicines sold in Great Britain rose from around $£ 0.5$ million per annum at the middle of the nineteenth century to $£ 4$ million about the turn of the century. The number of retail outlets licensed to sell patent medicines increased from 10,000 in 1865 to over 40,000 in 1905, of which approximately one-third were run by qualified chemists. Chapman, op. cit., note 5 above, pp. 23, 26, 203-205.

82 Similar fees to those paid in the late-eighteenth century. For example, William Lawton, chemist and druggist of Wakefield, took Jonathon Lawton (the presumed family relationship is not known) as apprentice in 1783 for two years at a fee of $£ 21$ per annum. In 1788, he took another apprentice, Joseph Fearnley, who, lacking a family connexion, paid a fee of $£ 50$ per annum for a four-year term. Wallis, op. cit., note 10 above. For the education of chemists and druggists, see M. P. Earles, 'The pharmacy schools of the nineteenth century' in Poynter (editor), op. cit., note 2 above, pp. 79-95.

${ }^{83}$ Huddersfield Examiner, 28 January 1860.

${ }^{84} \mathrm{~W}$. White, West Riding Yorkshire directory, Leeds, 1828; Census enumerators' books, Huddersfield Township, 1851; Kelly's directory of Huddersfield and neighbourhood, London, 1881.
} 


\section{The medical activities of mid-nineteenth-century chemists and druggists}

Chemists and druggists also enjoyed the advantages of accessibility, their shops being open for long hours, with a druggist usually in attendance. Many druggists, particularly those retailing in predominantly working-class areas, continued to live over their shops. With the advantages that continuity, familiarity, and accessibility brought, some achieved considerable local fame. John Gartside Elliot, a mid-century Sheffield chemist and druggist, was believed to have a great knowledge of human ailments, and even to be gifted with second sight. He gave the poor free advice and medicines, and was especially noted for his "big pennyworths" of drugs. His shop was generally packed with customers from opening time at noon until late at night. ${ }^{85}$ The establishment of George Hall (the prosperous individual discussed above) was "... believed in as a cure-all with a faith greater than ever Gull or Jenner commanded, ..." by the people of Huddersfield ${ }^{86}$ When R. C. Walshaw became successor to George Hall, "The People's Druggist", in the 1890s, his druggist's shop was then one of the oldest in the town. Walshaw promised to give personal attention to the preparing of medicines for small ailments ". . for which the late Geo. Hall was so justly noted". 87

Still largely free from ethical, professional, or legal restrictions, the chemist could sell what he chose to whom he chose, make use of extensive publicity, and make excessive claims for his products. The chemist and druggist had a wide appeal, offering a range of products, traditional herbal remedies, patent cure-alls, homeopathic, botanic, hydropathic, and allopathic remedies, sometimes specializing, but never excluding other lines from his shop. Self-medication was still attractive to many groups of society, and the chemist catered very much for this demand. This group also provided drugs and advice in cases where individuals may have been reluctant to seek the aid of a qualified practitioner (often with justification in that assistance in the form required may not have been forthcoming)-for instance, in the procurement of abortions, birth control, the treatment of venereal diseases, and the provision of opiates on "demand. Cost was a further factor that ensured the continuing popularity of the chemist and druggist, many of his products being available for as little as several shillings or pence, while advice was given gratis provided, presumably, that it accompanied the sale of medicine. Meanwhile, by the mid-nineteenth century, the minimum fee generally charged for one visit by a general practitioner was approximately $5 s$., excluding medicines. More complicated courses of treatment or visits by consulting physicians or surgeons could cost upwards of several guineas. Meanwhile, Poor Law medical services and charitable provisions failed to expand in many urban communities to meet the needs of the rapidly growing population, thus exacerbating the demand for medical care, and, in effect, offering increased opportunities for the chemist and druggist. As has been demonstrated, the middle and upper classes do seem to have sought out the services of chemists and druggists. However, their largest pool of custom was made up of members of the poor and working classes.

\footnotetext{
${ }^{85}$ Austen, op. cit., note 10 above, pp. 52-53.

${ }^{86} \mathrm{G}$. W. Tomlinson, History of Huddersfield (home words), 1885-1887 (newspaper extracts and essays), Huddersfield, 1887.

${ }^{87}$ County Borough of Huddersfield. Official handbook of Her Majesty's Diamond Jubilee celebration, June 22nd, 1897, Huddersfield, The Advertiser Press, 1897.
} 